\title{
Authoritarianism and the Challenge of Higher Education in the Age of Trump
}

\author{
Henry A. Giroux \\ McMaster University (Canada)
}

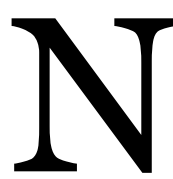

eoliberal capitalism is on the march fueling right wing populist movements across the globe, as is evident not only in the election of Donald Trump in the U. S. but also Doug Ford here in Ontario. Trump's election is seen by many as a vote against democracy and a vote on the side of a not so latent apocalyptic populism and emerging authoritarianism. How this movement will play out under Doug Ford's rule remains to be seen. For this talk, I will focus on the U.S. because I can't quite wrap my head around our new context. But I think we can learn a lot, and we need to learn a lot about what happens to higher education "when authoritarians win elections and a liberal democracy morphs into something else." 1

Under the regime of Donald Trump, higher education is under siege. Its oft stated purpose to produce the formative cultures necessary to support critical thinking, civic courage, expand the radical imagination, and nurture individual and social agency has been abandoned. To Trump and other right-wing populists, universities are objects of disdain. At the same time, the growing crisis of higher education is expanding across the globe and increasingly echoes H. G. Wells' remark in 1920 that "History is becoming more and more a race between education and catastrophe." Wells' comment is particularly prescient as authoritarianism gains in strength in the United States and a number of other countries. Higher education has been removed from a language that highlights the central question of what the role of learning might be not only in a democracy but also in a time of tyranny.

(C) Henry A. Giroux. The content of this article is the sole responsibility of the author. The ACT Journal and the Mayday Group are not liable for any legal actions that may arise involving the article's content, including, but not limited to, copyright infringement. 
In the current political administration, education appears to abet rather than challenge an ever-deepening ignorance and blind loyalty that newly defines community if not leadership and governance. Rather than being ashamed of this plunge into the fog of misrepresentation and illiteracy, the Trump administration parades it as a mark of strength and assurance, using it as a weapon to make oppressive power invisible and unassailable. After all, those who rely on arguments and evidence are critically suspect and apostles of "fake news"! Trump's slogan "Make America Great Again," translates not only into "Make America White Again," but also points to the need to normalize ignorance and white supremacist beliefs. Pressed into the service of violence, language in this administration is vomited up in waves of hate, racism, insults, and cruelty. This is the language of intolerance and walls, toxic impulses, and a vehicle for amplifying rather than solving crucial social problems.

Trump's brand of authoritarianism has emerged at a time in which there is an over abundance of information, coupled with the rise of new digital and visual media whose cognitive models reinforce the assumption that reality be echoed rather than interrogated and critically comprehended. Language has collapsed into mere utility, a lifeless metric, and a market-driven "machinery of social death."2 Reality TV and celebrity culture are the new models of popular education and mass communication, which when coupled with a society addicted to speed, overstimulation, and unchecked self-interest, create a powerful mode of pedagogy that blurs the line between reality and entertainment, fact and fiction, good and evil, and pleasure and sadism.

The power of language is now measured against its ability to move crowds, vanquish thought, fuel hatred, and flee into a "twittering cacophony of one-liners and promotional announcements." "Words cannot wait for thoughts," and as such the relationship between literacy and agency is undermined.4 This is not only a formula for the death of those public spheres that make a democracy possible, it is also a condition for the growth of authoritarianism. Hannah Arendt was right in insisting that the loss of historical memory and the rise of thoughtlessness are fundamental to the politics of demagogues and totalitarian societies. In the current moment, Trump's law and order rhetoric and ongoing demonization of select groups fuels what Robin Kelley calls the basis for a fascist state, that is, the intensification and acceleration of "racist-state sanctioned violence and the mass caging of black and brown people." 5 In the current historical moment, memory has no 
place in the dark cave of civic depravity-a space where freedom in the service of justice is abandoned in an educational ecosystem where nothing is true, and the basis for criticizing power collapses under the spectacle of presidential bomb throwing-like-tweets, endless spectacles of diversion, and high-level stretches of newspeak blather.

At a time when political extremists and warmongers have moved from the margins of politics to the center of power, a culture of fear and cruelty becomes the essence of politics reinforced by the denigration and erasure of any viable notion of morality and personal and social responsibility. As notions of social justice and political visions fall prey to a celebration of unchecked self-interest, greed is elevated to a national virtue along with a survival of the fittest ethos. In the age of "fake news" everything that matters withers, and institutions and public spheres that were meant to address crucial social issues and problems begin to vanish.

Under President Trump, the role of education in cultivating a critical citizenry capable of participating in and shaping a democratic society is being undermined, if not lost. Lost also is an educational vision that takes people beyond the world of common sense, functions as a form of provocation, teaches them to be creative, exposes individuals to a variety of great traditions, embraces the arts, and creates the pedagogical conditions for individuals to expand the range of human possibilities. Under the influence of corporate power and a growing authoritarianism in the United States, education in multiple informal and formal platforms operates increasingly in the service of lies, racism, unadulterated market values, and a fullfledged assault on critical consciousness and public values. Moreover, higher education is now dominated by a neoliberal discourse that removes it from its role as a democratic public sphere. Instead, it has become a financial investment and another workstation whose goal "is to ensure that young people, and society generally, can compete in a global economy." ${ }^{\prime}$ Under such circumstances, education becomes vocationalized, democracy is cast as the enemy of freedom, and politics turns dark.

These anti-democratic tendencies are evident in the ways in which neoliberalism since the 1980 s has reshaped formal education at all levels into a site for training, inundating market values, and imposing commercial relations as a template for governing all of social life. Every idea, social relationship, value, institution, and form of knowledge runs the risk of being economized, turned into a commodity, brand, or source of profits. Increasingly aligned with market forces, higher 
education is mostly primed for teaching business principles and corporate values, while university administrators are prized as CEOs or bureaucrats in an audit culture.7 Many colleges and universities have been McDonaldized as knowledge is increasingly viewed as a commodity resulting in curricula that resemble a fast-food menu. ${ }^{8}$ In addition, faculty are subjected increasingly to a Wal-Mart model of labor relations designed as Noam Chomsky points out "to reduce labor costs and to increase labor servility." 9 In the age of precarity and flexibility, the majority of faculty have been reduced to part-time positions, subjected to low wages, lost control over the conditions of their labor, suffered reduced benefits, and frightened about addressing social issues critically in their classrooms for fear of losing their jobs. The latter may be the central issue curbing free speech and academic freedom in the academy. Moreover, many of these faculty are barely able to make ends meet because of their impoverished salaries and some are on food stamps. ${ }^{10}$ If faculty are treated like service workers, students fare no better and are now relegated to the status of customers and clients. Moreover, they are not only inundated with the competitive, privatized, and market-driven values of neoliberalism, they are also punished by those values in the form of exorbitant tuition rates, astronomical debts owed to banks and other financial institutions, and in too many cases a lack of meaningful employment. ${ }^{11}$

Oppressive forms of education are also at work in the broader society where the educational force of the wider culture functions through a range of cultural apparatuses extending from the mainstream and conservative media to digital and online platforms that largely operate in the service of a corporate controlled media sphere that has become what Mort Rosenblum calls a "cesspool of misleading babble."12 In addition, Trump has managed to shape the cultural landscape in ways that have unleashed what I term a poisonous public pedagogy of sensationalism, easy consumption, bigotry, fear, and distraction. All the while, Trump fills the Twitter world with an ongoing bombast of emotional drivel.

Americans live in Kafkaesque times-a time in which the fight for justice has given way at the highest echelons of power to the legitimation of injustice. How else to explain Trump's claim that there were "very fine people on both sides" when referring to the deadly violence perpetrated in Charlottesville, Virginia by white nationalists, neo-Nazis, and members of the Klan, on the one hand, and those protesting such hatred, on the other. ${ }^{13}$ Trump's suggestion that there is a moral equivalency between neo-Nazis and those protesting their hate-filled ideology is 
frightening example of Trump's backing, if not endorsement, of the ideology of white supremacy and white nationalism.

Trump's endless tweet storms advocating various registers of apocalyptic populism is also a testimony to Pierre Bourdieu's insistence that "the most important forms of domination are not only economic but also intellectual and pedagogical and lie on the side of belief and persuasion." 14 In this instance, the pedagogical call to think, inspire, and energize has been replaced by a discourse and pedagogical practices designed to misdirect rage, deaden the ethical imagination, and encourage the collective fog of unchecked nihilism, racial purity, and a depoliticizing privatism. Trump's pedagogy is largely fashioned through his use of the social media, his support by conservative diffusion outlets such as Fox News, Breitbart News, and the Sinclair Broadcast Group, along with the aggressive support of extreme talk radio, all of which function as thinly veiled propaganda and disimagination machines. Trump's unrelenting pedagogical shocks to the body politics and civic culture have done more than lower the bar of civic discourse and the rules of governing, they have normalized the unimaginable.

I think it is fair to argue that the nightmarish vision of an impending American-style authoritarianism is no longer a product of dystopian fiction-found in the work of George Orwell, Aldous Huxley, Margaret Atwood, Ray Bradbury, and others. Under the regime of Donald Trump, the language of "Newspeak" has been normalized, functions through multiple platforms, and has morphed into a giant poisonous machinery of propaganda, violence, intolerance, hatred, and war. The latter is clearly visible in Trump's language and politics, which in its various forms has a low threshold for demonization, deportation, imprisonment, and savage hardships, especially for Muslims, undocumented immigrants, and African-Americans.

As Trump's White House works hard to eliminate expressions of discontent, resistance, and popular democratic struggles, the criminogenic machinery of power is on full display in the wider culture. Unapologetic forms of white supremacy, bigotry, and the growing tactics of a police state undermine the democratic mission of educational institutions in an age of increasing tyranny. Under such circumstances, the modern loss of faith in the coupling of education and democracy needs to be reclaimed, but that will only happen if the long legacy of struggle over education as a practice of freedom is once again brought to life as part of a more comprehensive understanding of education as being central to politics itself. Such 
a task is particularly urgent as the United States and other countries descend into the abyss of authoritarianism.

What happens to democracy when the President of the United States consistently lies? What happens to democracy when individuals and groups are demonized on the basis of their religion and ethnicity? What happens to a social order when the Secretary of Housing and Urban Development, Ben Carson, claims that Obamacare is worse than slavery and 9/11 and often subjects the poor to a culture of shaming? What happens to a society in which 400 families own as much wealth has half the population? What happens to a society that has only $5 \%$ of the world's population, but has more than $25 \%$ of the world's prison population, making it the world's largest jailer? What kind of society burdens students with thousands of dollars in debt? What are we to make of a society in which school children, sometimes as young as seven years old, are put in hand cuffs and put in the criminal justice system for acting out, doodling on a desk, or violating a dress code? What forces have allowed education to be undermined as a democratic public sphere, capable of producing the formative culture and critical citizens that could have prevented such a catastrophe from happening in an alleged democracy? What does the election of Donald Trump and the rise of illiberal democracies all over the globe suggests about the role of higher education in a time of tyranny? What does the authoritarianism that is emerging on our southern border suggest about developing forms of resistance in higher education that as James Baldwin, once put it, inspire and energize us to "go for broke?" When does silence betray complicity and inaction a moral and intellectual failing? What does it mean to refuse to define higher education as a crucial democratic public sphere in dangerous times?

We get a glimpse of this failure of civic literacy, education, and public values in the willingness and success of the Trump administration to empty language of any meaning, a practice that constitutes a flight from historical memory, ethics, justice, and social responsibility. Under such circumstances, Orwell's "Ignorance is Strength" materializes in the Trump administration's weaponized attempt not only to rewrite history, but also to obliterate it. What we are witnessing is not simply a political project but also a reworking of the very meaning of education both as an institution and as a cultural force.

As ignorance becomes one of the primary organizing principle of American society, all traces of critical thought migrate to the margins of the culture. For instance, two thirds of the American public believe that creationism should be taught 
in school, $20 \%$ believe "an alien life form has abducted a friend or family member of theirs," 15 a majority of Republicans in Congress believe that climate change is a hoax, and " $51 \%$ of Republicans believe that Barack Obama was born in Kenya. ${ }^{16}$ This stuff is hard to make up and makes the U.S. the object of ridicule and the laughing stock of much of the globe. ${ }^{17}$

Politicians endlessly lie knowing that the public is addicted to exhortation, emotional outbursts, and sensationalism, all of which mimics the crassness of a culture in crisis. Image selling now entails lying on principle, making it easier for politics to dissolve into entertainment, pathology, and a unique brand of criminality. Any assertion of expertise or professional knowledge is increasingly viewed with skepticism, even disdain, as people turn to self-help therapies, Internet drivel, and the manufactured witlessness produced in celebrity culture.

Under an austerity-driven neoliberal project, education has defaulted on its willingness to create critical citizens necessary for the functioning of a democratic public sphere. In the more general sense, education is now viewed either as a form of mass entertainment, training, or aligned to market values and dominated by the imperatives of commercial exchange. The assault on higher education is just one more example of how market values erode the public good. Run as a business, higher education prioritizes profits over an education that enables an informed and creative citizenry, turns its back on democracy as a governing principle, and redefines higher education through what Wendy Brown calls "vulgar forms of marketization." 18

Defunded and corporatized, many institutions of higher education have been all too willing to make the culture of business the business of education, and the transformation has corrupted their mission. Across the United States the landscape and goal of higher education is changing so as to adopt the mission of business schools. This was made clear by Pat McCrory, the former governor of North Carolina, who argued in a barely veiled warning to faculty that higher education needed to adopt a brand that fits "the ever-changing competitive environment of the twenty first century [while producing] subjects employers need."19 Other threats to higher education come from conservative think tanks, far-right groups, and right-wing pundits who are monitoring faculty syllabi, calling for universities to teach the Great Books model of humanities education, and urging legislators and college administrators to eliminate tenure and academic institutes that address major social issues such as poverty and voter registration. In some cases, alt- 
right and neo-Nazi groups are issuing death threats against faculty who speak out against racism and other volatile social issues. ${ }^{20}$

Many of these policies are reminiscent of tactics either used by right-wing groups and ideological fundamentalists over the past century ${ }^{21}$ or mimic a script right out of the Ayn Rand neoliberal playbook. One example of the latter is on full display in the comments of John Allison, the former president of the Cato Institute, who once insisted that the only educational programs that should be funded are those that "retake the universities [back from] statist/collectivist ideas" in order to align them with an ideology that educates students about the virtues of capitalism which, as he puts it, without irony, are "clearly in our shareholders' long-term interest." 22

This assault on the democratic mission of higher education is not new to the United States, but I believe that what has developed under the reign of Trump is an accelerated attack on all public spheres, especially those whose function is to create an informed and critical citizenry, provide crucial social provisions, and ensure public health. Under the Trump regime, there has been an intensity and acceleration of this kind of violence. At work here is a deadening and radically dehumanizing neoliberal project which transforms the individual into a brand, education into training, and promotes a public pedagogy at odds with what poet Tracy K Smith refers to as "feelings of humility, shared vulnerability, doubt and trust." 23 In this savage political project, public servants are held in contempt, and the notion of the common good is viewed as incompatible with the needs of finance capital-a position Doug Ford appears to endorse.

As the social or welfare state is dismantled, the punishing state expands while the state is reduced to serving the interests of the financial and banking elite. Language itself is commodified as words such as love, trust, freedom, responsibility, and choice have been deformed by a market logic that narrows their meaning to either a commercial relationship or to a reductive notion of getting ahead. We don't love each other, we love our commodities. Instead of loving with courage, compassion, and desiring a more just society, we embrace a society saturated in commercial relations. Confined to the principles of a market fundamentalism, freedom now means removing one's self from any sense of social responsibility so one can retreat into privatized orbits of self-indulgence and unbridled self-interest. Under Trumpism, it is easy to forget Martin Luther King Jr's insistence that freedom is not simply freedom from outside interference, but must be viewed as the freedom 
to intervene in the world in order to embrace the principle that an "injustice anywhere is a threat to justice everywhere" and that "freedom is never voluntarily given by the oppressor; it must be demanded by the oppressed." 24

Democracy is now plagued by the acceleration of a more toxic form of illiteracy, one that is more than an absence of learning, ideas, or knowledge. On the contrary, it is a willful practice and goal used to actively depoliticize people and make them complicit with the forces that impose misery and suffering upon their lives. What are we to make of Trump's bold claim that he "loves the poorly educated"? 25 What are we to make of Trump's praise of Alex Jones, a conspiracy trafficker, who runs the website Infowars and believes that Sept. 11 was an "inside job" and that the massacre of children at Sandy Hook was faked? Why was there no populist revolt by his supporters for his endorsement of failed Alabama Senate candidate, Roy Moore, "who had eight allegations of child molestation and assault and inappropriate sexual behavior against him?" How are we to explain the silence if not endorsement by Trump supporters in the face of a right-wing press that spreads insane conspiracy theories such as the reprehensible claim that David Hogg, a student and journalist at Marjory Stoneman Douglas High School, is a "crisis actor" rather than a witness to mass shooting in which 14 students and 3 staff people were killed? The Republican Party in the United States is now led by ideological extremists. In fact, the face of that extremism was on full display recently when Arthur Jones-a Holocaust denier and former leader of the American Nazi Party-won the Republican nomination for the 3rd Congressional District seat in Illinois. The drumbeat of fascism is no longer a mere echo of the past.

What happens to democracy when the President of the United States labels critical media outlets as "enemies of the people" and derides the search for truth by endlessly tweeting lies and misrepresentations? What happens when the American public forgets that the last time the critical media was termed as a threat and enemy, it was a charge made by hard-core racial segregationist during the early stages of the civil rights movement in the 1960s? What happens to democracy when individuals and groups are demonized on the basis of their religion? What happens to a society when critical thinking and facts become objects of contempt and are disdained in favor of raw emotion or undermined by an appeal to what U.S. Counselor to the President, Kellyanne Conway, calls "alternative facts"? What happens to a social order ruled by an "economics of contempt" that blames the poor for their condition and subjects them to a culture of shaming? What happens to a 
public that retreats into private silos and becomes indifferent to the use of language in the service of a panicked rage that stokes anger but not about issues that matter? What happens to a social order when it treats millions of illegal immigrants as disposable, potential terrorists, and criminals? What happens to a country when the presiding principles of a society are violence and ignorance? What happens is that democracy withers and dies, both as an ideal and as a reality.

One of the challenges facing the current generation of educators, students, and others is the need to address the question of what education should accomplish in a society at an historical moment when it is slipping into the dark night of authoritarianism. What work do educators have to do to create the economic, political, and ethical conditions necessary to endow young people and the general public with the capacities to think, question, doubt, imagine the unimaginable, and defend education as essential for inspiring and energizing the citizens necessary for the existence of a robust democracy? In a world in which there is an increasing abandonment of egalitarian and democratic impulses, what will it take to educate young people and the broader polity to challenge authority and hold power accountable?

Given the crisis of education, agency, and memory that haunts the current historical conjuncture, educators need a new language for addressing the changing contexts and issues facing a world in which there is an unprecedented convergence of resources-financial, cultural, political, economic, scientific, military, and technological-increasingly used to exercise powerful and diverse forms of control and domination. Such a language needs to be self-reflective and directive without being dogmatic and needs to recognize that education is always political because it always presupposes a vision of the future, legitimizes specific forms of knowledge, values, and social relationships, and in doing so produces particular forms of agency. Educators need a language that allows people to invest something of themselves, to recognize in it their lived experiences, and enables them to speak critically to their condition. We need a language that connects everyday troubles to wider structures and presses the claim for economic and social justice.

At the heart of such a practice is the need to ask what is the role is of education in a democracy? What pedagogical, political, and ethical responsibilities should educators, musicians, artists, journalists, and other cultural workers take on at a time when there is an alarming rise of authoritarian regimes across the globe, especially in formally democratic countries such as Turkey, Hungary, Poland, and 
Italy. How can educational and pedagogical practices be connected to the resurrection of historical memory, new modes of solidarity, a resurgence of the radical imagination, and broad-based struggles for an insurrectional democracy? How can education be enlisted to fight what the cultural theorist Mark Fisher once called neoliberalism's most brutal weapon: "the slow cancellation of the future?"26

Such a vision suggests resurrecting a democratic project that provides the basis for imagining a life beyond a social order immersed in massive inequality, endless assaults on the environment, and elevates war and militarization to the highest and most sanctified national ideals. Under such circumstances, education becomes more than an obsession with accountability schemes, testing, market values, and an unreflective immersion in the crude empiricism of a data-obsessed marketdriven society. In addition, it rejects the notion that colleges and universities should be reduced to sites for training students for the workforce-a reductive vision now being imposed on public and higher education by high tech companies such as Facebook, Netflix, and Google who want to encourage what they call the entrepreneurial mission of education, which is code for collapsing education into training. ${ }^{27}$ Education and pedagogy should be ways of thinking about democracy, not simply training students to be workers.

A critical education recognizes that learning skills for the work place is no excuse for purging from education what it means to teach students how to think critically, embrace the common good, exercise a sense of social responsibility and support a world of values, feelings, and the ethical and political foundation necessary for a democratic society." 28 Yes, we must educate young people with the skills they need to get jobs, but as educators we must also teach them to learn "to live with less or no misery [and] to fight against those social sources" that cause war, destruction of the environment, "inequality, unhappiness, and needless human suffering." 29

There is an urgent political need for both Canada and the United States, among other countries, to understand what it means for an authoritarian society to weaponize and trivialize the discourse, vocabularies, images, and aural means of communication in a variety of education and cultural sites. I do not believe it is an overstatement to argue that education can all too easily become a form of symbolic and intellectual violence, one that assaults rather than educates. Education is never innocent and is always implicated in relations of power and specific visions of the present and future. But education does not have to be tied to power relations 
immersed in forms of domination. As we know from the 1960 s and more recent university protests, education is also a site of struggle and contains the promise of higher education as a democratic public sphere and pedagogy as a form of educated hope. As a form of educated hope, education in this sense is not an antidote to politics, a nostalgic yearning for a better time, or for some "inconceivably alternative future." Instead, it is an "attempt to find a bridge between the present and future in those forces within the present which are potentially able to transform it."30

One of the most serious challenges facing administrators, faculty, and students in colleges and universities is the task of developing discourses and pedagogical practices that connect reading the word with reading the world and doing so in ways that enhance the capacities of young people to translate private troubles into larger systemic issues, while transforming their hidden despair and private grievances into critical narratives and public transcripts. At best such transcripts can be transformed into forms of public dissent or what might be called "a moment of 'rupture"- - one that has important implications for public action in a time of impending tyranny and authoritarianism. ${ }^{3}$ In taking up this project, educators and others should attempt to create the conditions that give students the opportunity to acquire the knowledge and the civic courage necessary to make desolation and cynicism unconvincing and hope practical. Democracy cannot work if citizens are not autonomous, self-judging, curious, reflective, and independent-qualities that are indispensable for students if they are going to make vital judgments and choices about participating in and shaping decisions that affect everyday life, institutional reform, and governmental policy.

Democracy and politics itself are impoverished in the absence of those vital public spheres such as public and higher education that provide the conditions for students and others to recognize how to use the knowledge they gain, both to critique the world in which they live and, when necessary, to intervene in socially responsible ways in order to change it. Once again, I want to raise the question of what it would mean for educators to take seriously the notion that democracy should be a way of thinking about education-one that thrives on connecting equity to excellence and learning to modes of agency that embrace the demands of social responsibility and the virtues of the common good. The great Czech dissident Vaclav Havel once argued that politics followed culture. That is, he argued that politics is inextricably connected to how individual and social consciousness are 
shaped, experiences are narrated, and investments organized so as speak convincingly to people's needs, anxieties, and hopes.

We live in a historical moment in which cultural institutions, political power, and everyday life create a new historical configuration of power and repression. Overt repressive practices now find their match in powerful forms of subjective and ideological control. A culture of privatization, unchecked individualism, spectacularized violence, suffocating narcissism, sensationalism, and immediacy has produced modes of agency and identification that promote both a retreat from any sense of civic culture and shared citizenship and open the door for demagogues to manipulate the feelings of isolation and rage of the most vulnerable. The mix of power, culture, and everyday life imposes new educational demands on those of us who want to breathe life and hope into a future that refuses the authoritarian impulses of the present.

Let me conclude by pointing to several recommendations, however incomplete, that provide an alternative to some of the oppressive conditions now shaping higher education. ${ }^{32}$

\section{First, higher education needs to reassert its mission as a public good in order to reclaim its egalitarian and democratic impulses}

Educators need to initiate and expand a national conversation in which higher education can be defended as a democratic public sphere and the classroom as a site of deliberative inquiry, dialogue, and critical thinking, a site that makes a claim on the radical imagination and a sense of civic courage. At the same time, the discourse on defining higher education as a democratic public sphere can provide the platform for a more expressive commitment in developing a social movement in defense of public goods. What is crucial to recognize here is that higher education has lost its way under the influence of corporate forces, allowing the culture of business to become culture of higher education. In doing so, it has mimicked the worse dimensions of the market, viewing education largely as a commodity to be bought and sold for private advantage while undermining the power of faculty and students to live up to and resurrect the demands of global citizenship.

Giroux, Henry A. 2019. Authoritarianism and the challenge of higher education in the age of Trump. Action, Criticism, and Theory for Music Education 18 (1): 6-25. doi:10.22176/act18.1.6 


\section{Second, educators need to acknowledge and make good on the claim that a critically literate citizen is indispensable to a democracy}

This suggests placing ethics, civic literacy, social responsibility, and compassion at the forefront of learning so as to combine knowledge, teaching, and research with the rudiments of what might be called the grammar of an ethical and social imagination. This would imply taking seriously those values, traditions, histories, and pedagogies that would promote a sense of dignity, self-reflection, and compassion at the heart of a real democracy. Students need to learn to understand how power works across social, cultural, and political institutions so that they can learn how to govern rather than merely be governed. Education should be a place where students realize themselves primarily as critically engaged and informed citizens, contributing not simply to their own self-interest but to the well-being of society as a whole.

\section{Third, higher education needs to be viewed as a right, as it is in many countries such as Germany, France, Norway, Finland, and Brazil, ra- ther than a privilege for a limited few, as it is in the United States, Can- ada, and the United Kingdom}

Rather than burden young people with almost insurmountable debt, it should call people to think, doubt, question, and be willing to engage in dialogue that is both unsettling to common sense and supportive of a culture of questioning. In addition, it should shift not only the way people think but also encourage them to help shape for the better the world in which they find themselves. Pedagogy should not be confused with therapy or reduced to zones of emotional safety. Once again, it is a space that should disturb, a space of difficulty-a space that challenges complacent thinking. Such pedagogical practices should enable students to interrogate common-sense understandings of the world, take risks in their thinking, however troubling, and be willing to take a stand for free inquiry in the pursuit of truth, multiple ways of knowing, mutual respect, and civic values in the pursuit of social justice. Students need to learn how to think dangerously, or as Baldwin argued, go for broke, in order to push at the frontiers of knowledge while recognizing that the search for justice is never finished and that no society is ever just enough. These are not merely methodical considerations but also moral and political practices, 
because they presuppose the creation of students who can imagine a future in which justice, equality, freedom, and democracy matter and are attainable.

Fourth, in a world driven by data, metrics, and the replacement of knowledge by the over abundance of information, educators need to enable students to engage in multiple literacies extending from print and visual culture to digital culture

They need to become border crossers who can think dialectically, and learn not only how to consume culture but also produce it. This presupposes learning how to situate ideas, facts, and knowledge historically and relationally. Not only does history become a consequential resource for thinking and acting, but it also enables students to connect isolated issues to the development of a comprehensive vision of society that does not rely on banking modes of education, technical issues, insular disciplinary narratives, and deadening forms of instrumental learning.33 At stake here is the ability to perform a crucial act of thinking, that is, the ability to translate private issues into larger systemic concerns.

Fifth, there is a plague haunting higher education, especially in the United States, which has become the model for its unjust treatment of faculty

The American Association of University Professors points out that 70 percent of all part and full-time instructional positions are filled with contingent or non-tenure track faculty. In addition, more than 50 percent of faculty now occupy contingent full-time positions. ${ }^{34}$ Many of these faculty barely make enough money to afford basic necessities, have no or little health insurance, and are reluctant to speak out and be critical for fear of losing their jobs. Many adjuncts are part of what are called the working poor. Jordan Weissmann, writing for Slate, points to an analysis by the University of California-Berkeley's Center for Labor Research and Education which states that " 25 percent of part-time college faculty and their families now receive some sort public assistance, such as Medicaid, the Children's Health Insurance Program, food stamps, cash welfare, or the Earned Income Tax Credit.” This is an abomination and one consequence of the increasing corporatization of higher 
education. These faculty positions must be transferred into full-time positions with a path towards tenure and full benefits and security.

\section{Sixth, another serious challenge facing educators is the need to develop both a discourse of critique and possibility. Critical analysis is neces- sary to break through the fog of ignorance, be able to hold power ac- countable, and reveal the workings and effects of oppressive and unequal relations of power}

But critique without hope is a prescription for cynicism, despair, or civic fatigue. A culture of questioning is crucial to any viable notion of teaching and learning, but it is not enough. Students also need to stretch their imagination to be able to think beyond common-sense, the limits of their own experience, and the disparaging notion that the future is nothing more than a mirror image of the present. In this instance, I am not referring to a romanticized and empty notion of hope. Hope means living without illusions and being fully aware of the practical difficulties and risks involved in meaningful struggles for real change, while at the same time being radically optimistic. The political challenge of hope is to recognize that history is open and that the ethical job of education, as the poet Robert Hass has argued, is "to refresh the idea of justice going dead in us all the time." 35

The late world-renowned sociologist, Zygmunt Bauman, insisted that the bleakness and dystopian politics of our times necessitates the ability to dream otherwise, to imagine a society "which thinks it is not just enough, which questions the sufficiency of any achieved level of justice and considers justice always to be a step or more ahead. Above all, it is a society which reacts angrily to any case of injustice and promptly sets about correcting it." 36 While hope has fallen on hard times under the dark shadow of an emerging illiberal democracy, a sense of collective passion and struggle is far from a historical relic. A sense of collective passion is on the rise in the United States and elsewhere, a passion that is not unrelated to Leonard Bernstein's claim that "our reply to violence [is] to make music more intensely, more beautifully, more devotedly than ever before.” Bernstein is talking about the need to elevate art to a symbol of hope, to link passion and dreaming, agency and justice. Music, like politics, is the condition of both beauty and the launch of utopian dreams; it is the connection between desire and compassion practiced as a form of social hope. It is precisely such a collective spirit informing 
a resurgent politics that is being rewritten by many young people today in the discourses of critique and hope, emancipation and transformation. The inimitable James Baldwin captures the depth, which both burdens hope and inspires it. In The Fire Next Time, he writes: "The impossible is the least that one can demand ... generations do not cease to be born, and we are responsible to them ... the moment we break faith with one another, the sea engulfs us and the light goes out." It is one of the tasks of educators and higher education to keep the lights burning with a feverish intensity.

\section{About the Author}

Henry A. Giroux currently holds the McMaster University Chair for Scholarship in the Public Interest in the English and Cultural Studies Department and is the Paulo Freire Distinguished Scholar in Critical Pedagogy. His most recent books include: Neoliberalism's War on Higher Education (Haymarket 2014), The Violence of Organized Forgetting (City Lights 2014), Dangerous Thinking in the Age of the New Authoritarianism (Routledge, 2015), America's Addiction to Terrorism (Monthly Review Press, 2016), America at War with Itself (City Lights, 2017), The Public in Peril (Routledge, 2018) and American Nightmare: Facing the Challenge of Fascism (City Lights, 2018). Giroux is also a member of Truthout's Board of Directors. His website is www.henryagiroux.com.

\section{Notes}

${ }^{1}$ David Runciman, Is This How Democracy Ends? London Review of Books, Vol. 38 No. 23 (December 2016), pp. 5-6. Online:

https://www.lrb.co.uk/v38/n23/david-runciman/is-this-how-democracy-ends >.

${ }^{2}$ Joao Biehl, Vita: Life in a Zone of Social Abandonment (Berkeley: University of California Press, 2005), p. 14.

3 Leon Wieseltier, Among the Disrupted, International New York Times (January 7, 2015). Online: http://www.nytimes.com/2015/o1/18/books/review/amongthe-disrupted.html?_r=o

4 Leon Wieseltier, Among the Disrupted, International New York Times (January 7, 2015). Online: http://www.nytimes.com/2015/o1/18/books/review/amongthe-disrupted.html?_r=o

5 Robin D. G. Kelley, Birth of a Nation, Boston Review (Mar 6, 2017). Online: http://bostonreview.net/race-politics/robin-d-g-kelley-births-nation

Giroux, Henry A. 2019. Authoritarianism and the challenge of higher education in the age of Trump. Action, Criticism, and Theory for Music Education 18 (1): 6-25. doi:10.22176/act18.1.6 
${ }^{6}$ Danielle Allen, What is Education For? Boston Review (May 9, 2016). Online: http://bostonreview.net/forum/danielle-allen-what-education

7 Benjamin Ginsberg, The Fall of the Faculty (New York: Oxford University Press, 2011).

8 Ulrich Beck, Twenty Observations on a World in Turmoil (London: Polity Press, 2010, especially pages $53-59$.

9 Noam Chomsky, The Death of American Universities, Reader Supported News, (March 30, 2015). Online at: http://readersupportednews.org/opinion2/27775/29348-the-death-of-american-universities

${ }^{10}$ Jordan Weissmann, Someone Calculated How Many Adjunct Professors Are on Public Assistance, and the Number Is Startling, Slate (April 13, 2015). Online: http://www.slate.com/blogs/moneybox/2015/04/13/adjunct_pay_a_quarter_of_part_time_college_faculty_receive_public_assistance.html

${ }^{11}$ Creston Davis, The Time of the Intellectual-Activists Has Come, Truthout (November 4, 2017). Online: http://www.truth-out.org/opinion/item/42472-thetime-of-the-intellectual-activists-has-come

${ }_{12}$ Mort Rosenblum, The Loon Ranger; All the fits that are news to print, Reader Supported News (March 16, 2018). Online: https://www.amazon.com/FascismToday-What-HowEnd/dp/1849352941/ref=sr_1_1?s=books\&ie=UTF8\&qid=1521399237\&sr=1$1 \&$ keywords=fascism+today+what+it+is+and+how+to+end+it+by+shane+burley

${ }^{13}$ Rosie Gray, Trump Defends White-Nationalist Protesters: 'Some Very Fine People on Both Sides', The Atlantic (August 15, 2017). Online: https://www.theatlantic.com/politics/archive/2017/08/trump-defends-whitenationalist-protesters-some-very-fine-people-on-both-sides/537012/

14 Pierre Bourdieu and Gunter Grass, The 'Progressive' Restoration: A FrancoGerman Dialogue, New Left Review 14 (March-April, 2002), p. 2

15 Nico Lang, 14 Surprising Things Americans Don't Know, According To Poll Numbers, Thought Catalogue (October 7, 2013). Online: https://thoughtcatalog.com/nico-lang/2013/10/14-surprising-things-americans-dont-know-according-to-poll-numbers/

Giroux, Henry A. 2019. Authoritarianism and the challenge of higher education in the age of Trump. Action, Criticism, and Theory for Music Education 18 (1): 6-25. doi:10.22176/act18.1.6 
16 Julia Glum, Some Republicans Still Think Obama Was Born in Kenya as Trump Resurrects Birther Conspiracy Theory, Newsweek (December 11, 2017). Online: http://www.newsweek.com/trump-birther-obama-poll-republicans-kenya744195

17 Kristen Ellingboe and Ryan Koronowski, Most Americans Disagree With Their Congressional Representative On Climate Change, Thinkprogress (March 8, 2016). Online: http://thinkprogress.org/climate/2016/o3/o8/3757435/climatedenier-caucus-114th-new-research/

${ }^{18}$ Wendy Brown. Neoliberalized Knowledge, in Lisa Phillips, Johanna Burton, Shannon Jackson, Dominic Willsdon Public Servants: Art and the Crisis of the Common Good, (The MIT Press, 2016: Cambridge), p. 290.

19 Jedediah Purdy, Ayn Rand Comes to U.N.C., The New Yorker (March 19, 2015). Online: https://www.newyorker.com/news/news-desk/new-politics-atthe-university-of-north-carolina

${ }^{20}$ Colleen Flaherty, Old Criticisms, New Threats. Inside Higher Ed (June 26, 2017). Online: https://www.insidehighered.com/news/2017/06/26/professorsare-often-political-lightning-rods-now-are-facing-new-threats-over-their

${ }^{21}$ Mark Ensalaco, Chile Under Pinochet: Recovering the Truth (Philadelphia: University of Pennsylvania Press, 1999)

22 Ibid. Jedediah Purdy, Ayn Rand Comes to U.N.C...

23 Tracy K. Smith: 'Staying Human: Poetry in the Age of Technology', Washington Post (May 29, 2018). Online: https://www.washingtonpost.com/entertainment/books/tracy-k-smith-staying-human-poetry-in-the-age-oftechnology/2018/05/29/89ob6df2-629b-11e8-a768-

edo43e33fidc_story.html?utm_term=.bb7489b23126

24 Martin Luther King, Jr., Letter from Birmingham City Jail (1963), in James M. Washington, The Essential Writings and Speeches of Martin Luther King, Jr. (New York: Harper Collins, 1991), p. 290.

25 Tessa Stuart, Watch Trump Brag about Uneducated Voters, 'The Hispanics', Rolling Stone (February 24, 2016). Online: http://www.rollingstone.com/politics/news/watch-trump-brag-about-uneducated-voters-the-hispanics-20160224

${ }^{26}$ Mark Fisher, Ghosts of My Life: Writings on Depression, Hauntology and Lost Futures (London: Zero Books, 2014), p. 2

Giroux, Henry A. 2019. Authoritarianism and the challenge of higher education in the age of Trump. Action, Criticism, and Theory for Music Education 18 (1): 6-25. doi:10.22176/act18.1.6 
${ }^{27}$ Natasha Singer, The Silicon Valley Billionaires Remaking America's Schools, New York Times (June 6, 2017). Online: https://www.nytimes.com/2017/06/06/technology/tech-billionaires-education-zuckerberg-facebook-hastings.html?_r=o

${ }^{28}$ Zygmunt Bauman and Leonidas Donskis, Moral Blindness:

The Loss of Sensitivity in Liquid Modernity (London: Polity, 2013), p. 196.

29 Zygmunt Mohanty Bauman, Liquid Modernity (London: Polity Press, 2001), p. 215 .

${ }^{30}$ Terry Eagleton, The Idea of Culture (Malden, MA: Basil Blackwell, 2000), p.22.

${ }^{31}$ Barbara Falk, "Between past and future," Eurozine (May 26, 2011). Online: http://www.eurozine.com/between-past-and-future/

$3^{2}$ Stanley Aronowitz, What Kind of Left Does America Need?, Tikkun (April 14, 2014). http://www.tikkun.org/nextgen/what-kind-of-left-does-america-need

33 Stanley Aronowitz, Against Schooling (Boulder: Paradigm Publishers, 2008), p. 50.

34 See, Vanessa Guida, Kat Savino, and Shannon Azzato Stephens, Universities' Reliance on Contingent Faculty Endangers Free Speech on Campus, Guernica (September 22, 2017). Online: https://www.guernicamag.com/universities-reliance-contingent-faculty-endangers-free-speech-campus/

35 Cited in Sarah Pollock, Robert Hass, Mother Jones (March/April 1997). Online: http://www.motherjones.com/media/1997/o3/robert-hass/

${ }^{36}$ Zygmunt Bauman and Keith Tester, Conversations with Zygmunt Bauman (London: Polity Press, 2001), p. 19.

Giroux, Henry A. 2019. Authoritarianism and the challenge of higher education in the age of Trump. Action, Criticism, and Theory for Music Education 18 (1): 6-25. doi:10.22176/act18.1.6 